\title{
Conversation Analysis, Discursive Psychology and the study of ideology: A Response to Susan Speer
}

As many readers will no doubt anticipate, this short article and the paper to which it responds are just two turns in a much broader conversation between critical discourse analysts and conversation analysts about how to best study talk (see also Schegloff, 1997; 1998; 1999a and b; Wetherell, 1998; Billig, 1999a and b). It is perhaps inevitable that such a debate should emphasise the differences between these two analytic approaches, but it is also important to bear in mind that they share many things in common. Such a recognition is implicit within Susan Speer's paper in that, compared to mine and Margaret Wetherell's discursive analysis of hegemonic masculinity (Wetherell and Edley, 1999), she offers 'a more conversation analytic alternative' (my emphasis). One of the main claims of the present paper is that there is even less of a difference between our approaches than Speer seems to imagine. More specifically, I will demonstrate that her work, like ours, reveals there to be some significant problems attending a conversation analytic approach to studying men and masculinity.

Following from Schegloff (1997), Speer's main argument is that an adequate discursive psychology need not, and perhaps should not, 'venture further than the limits of the text to explain why participants say what they do' (emphasis in original - see abstract). She recommends that analysts restrict themselves to 'the orientations, meanings, interpretations, understandings etc. of the participants' (Schegloff, 1997; 166 emphasis in original) rather than reading people's discourse through various socio-political concepts ${ }^{1}$. It is on precisely this basis that she rejects the concept of hegemonic 
masculinity (Connell, 1995; Carrigan, Connell and Lee, 1985). It is discarded, not because of any conceptual vagueness or operational difficulties (see Wetherell and Edley, 1999), but because it fails to emerge as a participants' concern.

The concept of hegemony has its origins in the political theorising of Antonio Gramsci (1971). For me it is best understood, not as something separate from ideology, but as a state or condition of ideology. All ideology works by making what is partial or conditional appear as normal, natural and inevitable. A state of hegemony exists when a particular cultural understanding or practice comes close to achieving that aim; when it becomes widely taken-for-granted or common-sense. The main implication of all this for a conversation analytic approach to studying men and masculinity should be obvious. For in attempting to maintain a 'participants' orientation', C.A. renders itself particularly unsuited to researching questions of hegemony and ideology. For example, it has been shown that there is a norm of men dominating mixed sex conversations (e.g. Cameron, 1998; Coates, 1993). And yet for many years the fact that men routinely hogged the conversational floor seemed quite unremarkable. The ideological nature of these interactions ensured that it didn't become a participants' concern, although the evidence was all before us. For many critical psychologists, restricting one's analytic attention in the manner prescribed by C.A. not only invites missed opportunities, but it also risks a form of ideological complicity.

The concept of hegemony is part of the technical vocabulary of the contemporary social theorist. In this way it is no different from C.A. 
concepts like adjacency pairs, extreme case formulations and three-part lists (which, as Billig, 1999a points out, conversation analysts seem to have no problem importing into their analyses). Hegemonic masculinity may never get mentioned in name, but it is a mistake to imagine that what it describes is entirely absent from everyday talk. The point is that it may not be visible at the level of a single utterance or turn; more often than not, it requires an analysis of broader tracts of data. Moreover, a closer inspection of Speer's analysis reveal that, apart from the importation of C.A.'s technical vocabulary, she brings in a number of other concepts from 'outside' of the text. For example, in her analysis of Extract One (see pg. 17) she claims that David's discourse is oriented to the simultaneous avoidance of appearing 'effeminate' and a 'conformist'. Extract Two is explained in terms of the same person's desire to avoid seeming 'hypocritical' (see pg. 20). Yet, from a strictly Schegloffian point of view, it is difficult to see where these interpretations comes from. David certainly never mentions anything about 'effeminacy' and neither does he worry out aloud about being his own man. This is not to say that the dilemmas that Speer identifies are not at work. Indeed, I would agree that they are. However, the point is that Speer's analysis, like ours, is heavily dependent upon what she already knows about the cultural and ideological context in which such statements are made. The data themselves are not enough.

As part of her critique of Wetherell and Edley (1999), Speer claims that we reify the concept of hegemonic masculinity, treating it as something that exists outside of and prior to particular conversations (pg. 9 para 2)2. In a sense she is perfectly correct. As Foucault (1972) pointed out, discourse does indeed 'construct the objects of which it speaks'; that is, it serves to 
create a 'reality' which is then (i.e. historically) both described and sustained/ eroded by future discourse. This means that hegemonic masculinity can exist outside of any particular conversation in at least two different senses. First of all, it exists as (a rationale for) a particular way of being in the world. For example, if the dominant definition of masculinity emphasises the values of strength and vigour, then it can be said to exist in physical displays of muscle and violence. A V-shaped torso represents an instantiation of that ideal. It is not extra-discursive in the broader sense of the term, but it can certainly be seen as extraneous to a particular conversation. Secondly, hegemonic masculinity can exist as part of our common sense. Dominant definitions of masculinity are reproduced in a multitude of conversations which take place every minute of every day. What is more, as many feminists and gay theorists can testify, they are robust formulations, unlikely to be undone by any single conversational intervention. It takes time and concerted effort to change predominant cultural understandings. They are a force that has to be reckoned with.

In her analysis of Extracts One and Three, Speer notes that David and Ben produce what she describes as 'strikingly similar' constructions of masculinity. Yet from our perspective, of course, there is nothing very surprising about this. Once one takes a step backwards, away from the level of the local, to consider broader stretches of talk, it becomes quite clear that David and Ben are drawing upon a very common story of masculinity. It is only by breaking one's data up into small, discrete fragments that such regularities are lost. Of course, Speer is entirely right to point out that both David and Ben are in the business of mobilising this particular masculine identity in the local context of some face-threatening situations. However, 
our point is that such moves both trade upon and contribute towards a much broader challenge to the cultural dominance of 'macho' masculinity (see Edley and Wetherell, 1997 for further evidence of this trend).

Speer chooses to reject our two-sided - or dialogic - model of the relationship between discourse and the speaking subject in favour of something more uni-dimensional. She imagines that almost anything can be accounted for at the level of the local; that almost every feature of a conversation is, in some way, designed or purpose-built for the context in which it makes its appearance. However, we do not share her faith. For example, if we look again at Extract One we might note that David claims that he doesn't "live up to" the "laddish image", even, he goes on, "at the best of times". All Speer makes of these phrases is to suggest that the last represents an instance of an extreme case formulation (Pomerantz, 1986). Yet for us they are much more revealing. As far as I can see, these utterances make no 'positive' contribution to David's construction of self; indeed they get in the way. That is, as something to "live up to" and as something one might manage "at the best of times", these phrases celebrate the very identity from which, through his extreme case formulations, David is trying to distance himself. In other words, something of the celebrated status of macho masculinity clings to his act of dis-identification.

The tendency to see participants' talk as almost perfectly designed to accomplish a wide variety of interactional functions is, of course, a central feature of conversation analytical work (Edwards, 1997; Antaki and Widdicombe, 1998). So, for example, when in Extract Two David comes out with his 'hearably exasperated' (pg.20) "Well I d-hhh", he is seen by 
Speer as doing being troubled instead of simply being troubled. Likewise, what immediately follows in the transcript is interpreted as containing 'noticeably considered pauses', implying that David's hesitancy was for rhetorical effect rather than being, in some sense, indicative of his psychological state ${ }^{3}$. Fair enough. However, one is left to wonder why David constructed himself as incapable of being more sexually aggressive ${ }^{4}$. Surely, from the point of view of impression management, it would have been better for him to imply that he could 'pull the birds', but simply chose not to. It seems to me that there are several possible interpretations of why David constructed himself in the way he did. Perhaps it was an error or missed opportunity which David might put right given a similar discursive moment. Or maybe this tale of lacking self-confidence is a familiar one for him, a story that he routinely tells (about) himself and which acts as a narrative organising both his sense of identity and his inter-personal relationships. Thirdly, perhaps he is doing 'being honest', the kind of activity which is best achieved when 'admitting' one's imperfections. It seems to me that most conversation analysts would favour the final explanation insofar as it explains his utterances at an entirely local level. However, from where I stand, the other two possibilities look every bit as compelling. Conversation analysts are right to want to draw attention to the 'witcraft' (Billig, 1996) of ordinary speakers, but they should be aware that sometimes what is being celebrated is their own interpretative ingenuity.

\section{Nigel Edley \\ Faculty of Humanities Nottingham Trent University}




\section{Notes}

1. Although, somewhat confusingly, Speer also suggests that whilst particular forms of masculinity may be treated as real by the participants themselves, this does not provide the grounds for analysts to treat them likewise (see pg. 33)

2. Intriguingly, it could be that our ally here is none other than Harvey Sacks himself. For what else would he mean by the notion of 'readymade' or 'context-free' categories of discourse? (see Speer's article pg. 33).

3. And yet what allows conversation analysts to gloss something as a repair? Surely this relies upon an inherently psychological notion that people catch themselves saying something that they do not wish to say and so say something different. Wouldn't it be truer to the ethos of C.A. to see the 'repair' as a designed feature, to imagine (here) that David accomplishes something by talking about macho masculinity as first 'real' and then 'extreme'?

4. It is clear that Speer is guilty of a misreading here (see pg. 21). David constructs himself as both unwilling and incapable of trying to 'pull' women. His argument is that he wouldn't try even if he had the confidence (which, by implication, he suggests he hasn't got). 


\section{References}

Antaki, C. and S. Widdicombe (eds) (1998) Identities in Talk. London: Sage.

Billig, M. (1999a) 'Whose terms? Whose Ordinariness? Rhetoric and ideology in Conversation Analysis'. Discourse \& Society 10(4): 543558.

Billig, M. (1999b) 'Conversation Analysis and the Claims of Naivety'. Discourse \& Society 10(4): 572-576.

Billig, M. (1996) Arguing and Thinking. (2nd. ed.) Cambridge: Cambridge University Press.

Cameron, D. (1998) (ed.) The Feminist Critique of Language: A Reader. (2nd ed.) London: Routledge.

Coates, J. (1993) Women, Men and Language (2nd ed.) London: Longman.

Connell, R.W. (1995) Masculinities. Cambridge: Polity.

Carrigan, T., R.W. Connell and J. Lee (1985), Towards a new sociology of masculinity. Theory and Society, 14, 551-604.

Edley, N. and M. Wetherell (1997) 'Jockeying for Position: The Construction of Masculine Identities'. Discourse and Society, 8(2): 203-217.

Edwards, D. (1997) Discourse and Cognition. London: Sage.

Foucault, M. (1972) The Archaeology of Knowledge. London: Tavistock.

Gramsci, A. (1971) Selections from Prison Notebooks London: Lawrence and Wishart. 
Pomerantz, A. (1986) Extreme case formulations: a way of legitimizing claims. Human Studies, 9: 219-29.

Schegloff, E.A. (1997) 'Whose Text? Whose Context?' Discourse \& Society 8(2): 165-87.

Schegloff, E.A. (1998) 'Reply to Wetherell' Discourse \& Society 9(3): 41316.

Schegloff, E.A. (1999a) "'Schegloff's Text as Billig's Data": A Critical Reply'. Discourse \& Society 10(4): 558-72.

Schegloff, E.A. (1999b) 'Naivete vs Sophistication or Discipline vs SelfIndulgence: A Rejoinder to Billig'. Discourse \& Society 10(4): 57782.

Wetherell, M. (1998) 'Positioning and Interpretative Repertoires:

Conversation Analysis and Post-Structuralism in Dialogue', Discourse and Society, Vol. 9(3): 387-412.

Wetherell. M and N. Edley (1999) 'Negotiating Hegemonic Masculinity: Imaginary Positions and Psycho-Discursive Practices'. Feminism and Psychology, Vol. 9 (3) 335-356. 